\title{
Assessment of Heavy Metal Pollution in a Columbite/Tantalite Mining Site in Edege- Mbeki, North Central Nigeria
}

\author{
*ISAH, ME, NUHU, AA, PAUL, ED \\ Department of Chemistry, Ahmadu Bello University, Zaria, Nigeria \\ *Corresponding Author Email: mohdisah048@gmail.com
}

\begin{abstract}
The release of pollutants due to mining activities, especially tailings, has negative consequences on soil and affects agricultural productivity. This study details the assessment of metals $(\mathrm{Ni}, \mathrm{Mn}, \mathrm{Pb}, \mathrm{Cd}$ and $\mathrm{Fe})$, physicochemical parameters of the soil and how they affect metal bioavailability and biotoxicity. Metal concentrations were determined using Atomic Absorption Spectrophotometer (AA-6800 Shimadzu). The results of the analysis show that the mean $\mathrm{pH}$ varied from a minimum of $7.12 \pm 0.36$ to a maximum of $7.60 \pm 0.28$ across all the study area and sampling points. The percent organic matter had an average minimum value of $0.13 \pm 0.08 \%$ and a maximum value of $0.82 \pm 0.32 \%$ in the study area. The heavy metal analysis result shows that concentrations in all the soil and sediments of the study area were all below the maximum permissible limit. Mean concentrations of $\mathrm{Ni}, \mathrm{Mn}, \mathrm{Cd}, \mathrm{Pb}$ and $\mathrm{Fe}$ had minimum values of $1.45 \pm 0.56,43.3 \pm 0.43,1.11 \pm 0.22,5.50 \pm 0.28$ and $522 \pm 0.88 \mathrm{mg} / \mathrm{kg}$ respectively, and the mean maximum concentrations had values of $11.70 \pm 0.90,200 \pm 0.17,20.7 \pm 0.11$, $31.0 \pm 0.78$ and $2716 \pm 0.83 \mathrm{mg} / \mathrm{kg}$ respectively. The findings show no metal contamination. However, the enrichment factor and contamination factor revealed that the presence of $\mathrm{Ni}, \mathrm{Mn}, \mathrm{Cd}$ and $\mathrm{Cd}$ in soil samples of the study area may be due to anthropogenic activities of mining.
\end{abstract}

\section{DOI: https://dx.doi.org/10.4314/jasem.v23i11.6}

Copyright: Copyright (C) 2019 Isah et al. This is an open access article distributed under the Creative Commons Attribution License (CCL), which permits unrestricted use, distribution, and reproduction in any medium, provided the original work is properly cited.

Dates: Received: 07 October 2019; Revised: 11 November 2019; Accepted 24 November 2019

Keywords: Heavy metals, Edge-Mbeki, Physiochemical, Contamination.

Since the beginning of the industrial revolution, soil pollution by toxic metals has accelerated dramatically (Nriagu 1996). It is now well recognized that industrial activities like mining, smelting, refining and manufacturing processes led to a substantial accumulation of about $90 \%$ of heavy metals in soil on a global scale from industrial activities (Nriagu, 1996). Several chemical industries in the coastal areas have resulted in a significant discharge of industrial effluents, including heavy metals into the coastal water bodies. These toxic effluents released into the environment cause a variety of toxic effects on the food chain (Dembitsky, 2003) by bioaccumulation and biomagnification (Manohar et al. 2006). Several researches were prompted due to the adverse effects of heavy metals on both plants and animals. All plants can accumulate both essential metals (Fe, Mn, Zn etc.) required for normal plant growth and metabolism and non-essential metals (Al, $\mathrm{Cd}, \mathrm{Pb}$ etc.) (Ologundudu et al., 2019). However, when these metals are above the threshold level, there is a possibility of poisoning to individual plants (Garrido et al. 2002). For example, elevated level of heavy metals in soil can result in enhanced crop uptake alongside negative effects on plants growth (Schmidt 2003), such as damaging the cell structure and inhibiting a number of cytoplasmic enzymes (Assche et al. 1999), and replacement of essential nutrients at cation exchange sites in plants
(Taiz et al. 2002). According to Ologundudu (2019), among all the heavy metals, Cadmium (Cd), Lead $(\mathrm{Pb})$, Chromium (VI), and Chromium (III) are highly toxic to plants, animals, and humans as well as soil microorganisms. For instance, high level of $\mathrm{Pb}$ in the soil is linked with decreased soil productivity as well as inhibiting important processes such as mitosis, photosynthesis, water absorption, and vegetative growth (Bhattacharya et al. 2008). To evaluate the damages that Columbite/Tantalite (COLTAN) mining activities have on the environment, considering that crude methods of mining are still largely used, it is imperative to assess the extent of pollution. Therefore, in order to evaluate the impacts mining activities have on the soil and agricultural productivity, especially considering that old methods of mining activities are still being practiced, the study was aimed at assessing the levels of metals ( $\mathrm{Ni}, \mathrm{Mn}, \mathrm{Pb}, \mathrm{Cd}$ and $\mathrm{Fe}$ ) in soil and sediment samples in Columbite/Tantalite mining areas in Edege-Mbeki mining district of North Central Nigeria.

\section{MATERIALS AND METHODS}

The study was carried out in a Columbite/Tantalite (COLTAN) mine located in Edege-Mbeki Mining district in Nasarawa State. The site is located in Nasarawa local government, in Edege development 
area. The study and control sites are located on the geographical coordinates of latitude $08^{\circ} 19^{\prime} 30^{\prime \prime} \mathrm{N}$ and longitude $70^{\circ} 50$ ' $80^{\prime}$ ' E.

Soil samples pretreatment: Soil and sediment samples were randomly collected at the different mining locations in Edege-Mbeki mining district. Control samples were taken at Maraban-Edege about 15 kilometres away from the mining district. The control site has no record of any mining activities but has human interference. Soil samples were collected at the surface $(0-15 \mathrm{~cm})$ and subsurface $(15-30 \mathrm{~cm})$ as well as sediments (Bank 1 and 2) using an Auger and a meter rule at both mine and control sites. The collected soil and sediment samples were stored in polythene bags, correctly labelled and transported to the laboratory for further analysis. Upon arrival to the laboratory, the soil and sediment were air-dried for 1 week and sieved on a $<2 \mathrm{~mm}$ sieve for heavy metals analysis and $0.5 \mathrm{~mm}$ for physicochemical analysis. The physicochemical properties $(\mathrm{pH}$ and Organic matter) were analyzed using standard methods at the Soil Research Laboratory of the Institute for Agricultural Research (IAR) Zaria.

Determination of soil $\mathrm{pH}$ : Determination of soil $\mathrm{pH}$ was determined according to the method of Radojevic and Bashkin (2006). Exactly twenty (20) grams of airdried soil and sediment samples were weighed in triplicate into a $50 \mathrm{~cm}^{3}$ beaker and $20 \mathrm{~cm}^{3}$ of distilled water was added. The mixture was allowed to stand for 30 minutes with occasional stirring using a glass rod. The $\mathrm{pH}$ measurement was taken using a Hanna digital $\mathrm{pH}$ meter which was initially calibrated using a buffer solution of $\mathrm{pH} 7$. The calibrated $\mathrm{pH}$ meter was then inserted into the partly settled suspension and the $\mathrm{pH}$ measurement was taken.

Determination of soil organic matter: The organic matter content of the soil and sediment were determined titrimetically (Anderson and Ingram, 1993). Soil/sediment samples were ground with a laboratory mortar to give fine particles that could pass through a $0.5 \mathrm{~mm}$ sieve after which they were weighed in triplicate and transferred to an Erlenmeyer flask of $250 \mathrm{~cm}^{3}$ capacity. Exactly $10 \mathrm{~cm}^{3}$ of $1 \mathrm{M}$ potassium dichromate was pipetted into each flask followed by swirling to disperse the soil, this was followed by addition of $20 \mathrm{~cm}^{3}$ concentrated sulphuric acid. The flask was swirled gently until the soil and reagents solution have mixed thoroughly. The whole mixture was then allowed to stand for 30 minutes on a glass plate to allow for the oxidation of potassium dichromate to chromic acid. Exactly $100 \mathrm{~cm}^{3}$ of deionized water was added followed by the addition of 3 drops of ferroin indicator, after which the mixture was titrated against $0.5 \mathrm{M}$ ferrous sulphate solution until there was a colour change from dull green to turbid blue. The titration solution was further added in drops until the endpoint was reached indicated by the change of colour to brilliant green. Titration for the blank solution was also carried out in the same manner.

$$
\% O C=\frac{B-T}{\text { Mass }(g) o f \text { dried soil }}
$$

Where; $\% \mathrm{OC}=$ Percentage Organic Carbon, $\mathrm{B}=$ Blank Reading, $\mathrm{T}=$ Titre value or volume of Ferrous Sulphate Used, $\mathrm{CF}=$ Conversion factor (1.33)

$\%$ organic matter in soil $=\%$ organic carbon $\mathrm{x} 1.729$ Heavy Metal Analysis: Digestion of soil/sediment sample was done according to Tsafe et al (2012). The soil/sediment sample was ground and sieved on a $2 \mathrm{~mm}$ sieve at the department of Geology. Exactly $0.5 \mathrm{~g}$ of soil/sediment was weighed and put into a beaker. Then a measured volume of $15 \mathrm{ml}$ of $30 \%$ hydrogen peroxide was added. This was left to stand for $60 \mathrm{mins}$ until the vigorous reaction ceased. Next $15 \mathrm{ml}$ of concentrated $\mathrm{HCl}$ was added and the content heated gently at low heat on a hot plate for about 2 hours. The digest was then removed from the digester and allowed to cool to room temperature. The digest was then filtered into $25 \mathrm{ml}$ standard flask and made up to the mark with distilled water. Triplicate digestion of each sample was carried out. Determination of the heavy metals as well as the standards were carried out in an atomic absorption spectrophotometer (model AA240FS). The values obtained in ppm after analysis were converted to $\mathrm{mg} / \mathrm{kg}$ for the soil samples.

The heavy metals of the samples (Ni, Mn, Cd, Pb, and Fe) were carried out using an Atomic Absorption Spectrophotometer (AAS 240FS) at the Multi-User Research Laboratory (MUSRL) of Ahmadu Bello University Zaria.

Assessment of Heavy Metal Pollution: The following parameters were used to assess the pollution level in the soil and sediments;

$$
C F=\frac{\text { concentration of Metal in Sample }}{\text { Concentration of Metal in Backgrou nd }}
$$

\section{Where $\mathrm{CF}=$ Contamination Factor}

The USEPA (1993) maximum contaminant limit of heavy metal in soil was used as the baseline or 
background metal levels for the calculation of contamination factors of soil and sediment samples.

Pollution Load Index (PLI): This index has been used for pollution assessment of heavy metals in soils and sediments sample (Bhupander et al., 2011). The pollution load index (PLI) for each site was calculated using the following relation,

$$
P L I=\sqrt[n]{C F 1 X C F 2 X C F 3 X \ldots X C F n}
$$

Where CF is the contamination factor of each metal that was examined while $\mathbf{n}$ equals the number of contaminants evaluated. A PLI value of 1 indicates pollution whereas PLI value less than 1 indicates no pollution (Ong et al. 2012).

Enrichment Factor (EF): An enrichment factor is a parameter that is used to evaluate natural or anthropogenic sources of heavy metal content in the soil and water (Ata et al. 2009). This index was used to distinguish between natural and anthropogenic sources. To calculate the enrichment factors for the entire elements, Iron (Fe) was used as a reference element.

$$
E F=\frac{\left[\left(\frac{C n}{C F e}\right)\right] \text { Sample }}{\left[\left(\frac{C n}{C F e}\right)\right] \text { Shale }}
$$

Where $(\mathrm{Cn} / \mathrm{Cfe})$ sample is the ratio of the concentration of the element of concern $(\mathrm{Cn})$ to that of $\mathrm{Fe}$ in the sediment sample and $(\mathrm{Cn} / \mathrm{Cfe})$ shale is the same ratio in an unpolluted reference sample.

\section{RESULTS AND DISCUSSION}

The results of physicochemical properties of soil and sediment samples are presented in Table 1. The $\mathrm{pH}$ of both the mining and control sites for surface $(0-15 \mathrm{~cm}$ deep) and subsurface (15-30 cm deep) level in EdegeMbeki and control is slightly alkaline. According to Mapanda et al. (2004), acidic soil aids in the absorption of heavy metals and dissolution of metal carbonates complexes. Hence, the $\mathrm{pH}$ may not have played any role in heavy metals absorption or dissolution in the study area. In the control site soil, percentage organic matter was found to be greater than the mining sites at both surface and subsurface levels. At $0-15 \mathrm{~cm}$ (subsurface layer), the control site gave a mean value of 0.82 against the mine site 0.18 . At the subsurface layer, the mining site gave a mean value of 0.17 against the control site of 0.31 . This is probably due to the mining activities that have stripped the mining district soil of its rich organic nutrient in the soil. Generally, the value of the soil and sediement organic matter $(\% \mathrm{OM})$ was observed to decrease in moving downward across the soil depth. This is normal since more biological activities usually take place at the upper level of the soil which decreases on moving down the depth of the soil profile (Majiya et

\begin{tabular}{|c|c|c|c|}
\hline Soil Parameters & 0-15 cm Deep & $15-30 \mathrm{~cm}$ deep & Sediment \\
\hline & Mining Site Control & Mining Site Control & Bank 1 \\
\hline $\mathrm{pH}$ & $7.54 \pm 0.40 \quad 7.12 \pm 0.36$ & $7.52 \pm 0.25 \quad 7.06 \pm 0.41$ & $7.60 \pm 0.287 .48 \pm 0.40$ \\
\hline$\%$ Organic Matter & $0.18 \pm 0.10 \quad 0.82 \pm 0.32$ & $0.17 \pm 0.100 .31 \pm 0.31$ & $0.19 \pm 0.020 .13 \pm 0.08$ \\
\hline
\end{tabular}
al., 2015).

\begin{tabular}{|c|c|c|c|c|c|}
\hline \multirow[t]{2}{*}{ Elements } & 0-15 cm Deep & \multicolumn{2}{|c|}{$15-30 \mathrm{~cm}$ deep } & \multicolumn{2}{|l|}{ Sediment } \\
\hline & Mining Site & Mining Site & Control & Bank 1 & Bank 2 \\
\hline $\mathrm{Ni}$ & $5.38 \pm 0.72 \quad 6.64 \pm 0.10$ & $11.7 \pm 0.9$ & $4.73 \pm 0.39$ & $1.45 \pm 0.56$ & $2.25 \pm 0.18$ \\
\hline Mn & $119 \pm 2.62 \quad 105 \pm 0.19$ & $71.0 \pm 1.9$ & $43.3 \pm 0.43$ & $134 \pm 0.6$ & $200 \pm 0.17$ \\
\hline $\mathrm{Cd}$ & $2.18 \pm 1.03 \quad 20.7 \pm 0.11$ & $1.11 \pm 0.22$ & $14.7 \pm 0.47$ & $1.45 \pm .00$ & $1.35 \pm 0.07$ \\
\hline $\mathrm{Pb}$ & $16.3 \pm 0.22 \quad 16.2 \pm 0.64$ & $5.50 \pm 0.28$ & $14.6 \pm 0.34$ & ND & $31.0 \pm 0.78$ \\
\hline $\mathrm{Fe}$ & $2716 \pm 0.83 \quad 887 \pm 0.40$ & $1676 \pm 0.4$ & $522 \pm 0.88$ & $539 \pm 0.94$ & $578 \pm 0.94$ \\
\hline
\end{tabular}

Table 2: Average values $(\mathrm{mg} / \mathrm{kg})$ of heavy metals soil and sediment samples

Mining site $=$ Edge-Mbeki, Control = Maraban-Edege, Bank 1= Mining Pond, Bank 2 = Tailings Pond, ND- Not detected.

Heavy Metals Level in Soil: The mean values of heavy metals in soil and sediment samples from the study area is shown in Table 2. The values obtained for all the soil/sediment samples were far lower than the USEPA (1993) maximum contaminant limit of $75 \mathrm{mg} / \mathrm{kg}$ for Nickel $(\mathrm{Ni})$ in the soil. The highest concentration of $\mathrm{Mn}(200 \pm 0.17 \mathrm{mg} / \mathrm{kg})$ at the entire study area was obtained in sediment sample "Bank sediment 1" of Edege-Mbeki mining pond. The values obtained for all the soil/sediment samples were below the US-EPA (1993) maximum contaminant limits of $850 \mathrm{mg} / \mathrm{kg}$. This implies that all the samples analyzed in this study area are not contaminated with manganese. Generally, there was a downward decrease in the concentration of Mn across all the soil depth profile $(0-15 \mathrm{~cm}, 15-30 \mathrm{~cm})$ in the entire sampling site. The values obtained for Cadmium decreases downward across the soil depth profile $(0-15 \mathrm{~cm}, 15-30 \mathrm{~cm})$ at all the sampling sites. 
The highest concentration of $\mathrm{Cd}(20.71 \pm 0.11 \mathrm{mg} / \mathrm{kg})$ was observed at $015 \mathrm{~cm}$ depth of Mararaban-Edege and the lowest concentration of $\mathrm{Cd}(1.33 \pm 0.04 \mathrm{mg} / \mathrm{kg})$ was observed at the mining pond sediment "Bank sediment 2". The values obtained for all the soil and sediment samples were below the US-EPA (1993) maximum contaminant limits of $85 \mathrm{mg} / \mathrm{kg}$. The highest concentration of $\mathrm{Pb}(31.0 \pm 0.78 \mathrm{mg} / \mathrm{kg})$ was obtained at Edege-Mbeki (Bank sediment 2) while the lowest concentration $(5.50 \pm 0.28 \mathrm{mg} / \mathrm{kg})$ was obtained at the depth of $15-30 \mathrm{~cm}$. In this research work, all the soil and sediments samples were below the US-EPA (1993) maximum contaminant limits of $450 \mathrm{mg} / \mathrm{kg}$ for $\mathrm{Pb}$ in the soil. The highest concentration of Fe (2716 $\pm 0.83 \mathrm{mg} / \mathrm{kg}$ ) was observed at $0-15 \mathrm{~cm}$ soil depth (Edege-Mbeki) and the lowest concentration of $\mathrm{Fe}$ $(522.91 \pm 0.88 \mathrm{mg} / \mathrm{kg})$ was observed at $15-30 \mathrm{~cm}$ soil depth of control (Mararaban-Edege). The values obtained for all the soil/sediment samples were lower than the US-EPA (1993) maximum contaminant limit of $47200 \mathrm{mg} / \mathrm{kg}$. Heavy metals contamination of soil can hinder microbial activities leading to low organic matter mineralization that is required for plant growth (Dai et al., 2004). The apparent increase of heavy metals concentration (not in all cases) in mine site and sediment compared to the control site points to the fact that mining waste is a potential source of soil contamination. An increasing level of these metals presents the site as potentially hazardous and could alter the food chain and biological life in the environment (Ologundudu et al., 2019).

Heavy Metals Contamination Factors (CF) of Soil Samples and Pollution Load Indices (PLI): Calculated contamination factors of the heavy metals under study and their pollution load indices (PLI) are shown in Table 3. Generally, except for Cadmium (Cd) in Edege-Mbeki (7.2767) at a soil depth of $0-15 \mathrm{~cm}$, there was low contamination of these metals $(\mathrm{Ni}, \mathrm{Mn}, \mathrm{Pb}$, $\mathrm{Cd}$ and $\mathrm{Fe}$ ) in all of the soil and sediment samples of Edege-Mbeki. However, there was very high contamination $(\mathrm{CF}>>6)$ of $\mathrm{Cd}$ in all the soil samples of Mararaban-Edege while all the other metals recorded low contamination of these metals $(\mathrm{Ni}, \mathrm{Mn}, \mathrm{Pb}$, and Fe). The highest contamination of Cadmium (69.043) was observed at Mararaban-Edege at a soil depth profile of $0-15 \mathrm{~cm}$, while the soil samples of EdegeMbeki recorded the least contamination (3.6767) of $\mathrm{Cd}$. The PLI value $>1$ indicates pollution whereas PLI $<1$ indicates no pollution (Ong et al. 2013). In the entire soil sampling site, PLI value calculated for heavy metals was ranged between 0.1793 and 0.3826 , which indicates that there was no serious overall load of heavy metals pollution or contamination in the entire sampling site.

Table 3: Heavy metals contamination factors (CF) and pollution load indices (PLI) of the soil and sediment samples

\begin{tabular}{lcccccc}
\hline \multirow{2}{*}{ Location/site } & \multicolumn{7}{c}{ Contamination factor (CF) } & \multirow{2}{*}{ PLI } \\
\cline { 2 - 6 } & $\mathrm{Ni}$ & $\mathrm{Mn}$ & $\mathrm{Pb}$ & $\mathrm{Cd}$ & $\mathrm{Fe}$ & \\
\hline & \multicolumn{7}{c}{ Edege - Mbeki } \\
\hline $0-15 \mathrm{~cm}$ & 0.0747 & 0.141 & 0.0816 & 7.2767 & 0.0576 & 0.2048 \\
$15-30 \mathrm{~cm}$ & 0.1713 & 0.0835 & 0.2750 & 3.6767 & 0.0355 & 0.2198 \\
Average & 0.1604 & 0.1123 & 0.1783 & 5.4767 & 0.0466 & 0.3826 \\
\hline \multicolumn{7}{c}{ Edege Mining ponds } \\
\hline Bank sediment 1 & 0.0331 & 0.2359 & 0.5513 & 4.50 & 0.0123 & 0.2319 \\
Bank sediment 2 & 0.0213 & 0.1579 & - & 4.8333 & 0.0114 & 0.1793 \\
Average & 0.0223 & 0.0898 & 2.0237 & 4.5833 & 0.0174 & 0.2096 \\
\hline & \multicolumn{7}{c}{ Mararaban - Edege } \\
\hline $0-15 \mathrm{~cm}$ & 0.0978 & 0.1247 & 0.0811 & 69.043 & 0.0188 & 0.2641 \\
$15-30 \mathrm{~cm}$ & 0.0696 & 0.0509 & 0.7332 & 48.833 & 0.0111 & 0.2689 \\
Average & 0.0837 & 0.0878 & 0.4072 & 58.938 & 0.0149 & 0.3047 \\
\hline
\end{tabular}

Table 4: Heavy metals Enrichment Factors (EF) of soil samples using Iron (Fe) as a reference element.

\begin{tabular}{lllll}
\hline \multirow{2}{*}{ Location/site } & \multicolumn{4}{c}{ Enrichment factor (EF) } \\
\cline { 2 - 5 } & $\mathrm{Ni}$ & $\mathrm{Mn}$ & $\mathrm{Pb}$ & $\mathrm{Cd}$ \\
\hline Edege - Mbeki & & & & \\
$0-15 \mathrm{~cm}$ & 1.375 & 2.444 & 14.309 & 125.87 \\
$15-30 \mathrm{~cm}$ & 4.826 & 2.351 & 7.741 & 103.84 \\
Average & 3.101 & 2.396 & 11.025 & 114.86 \\
Mining Ponds sediments & & & & \\
Bank sediments 1 & 2.701 & 19.24 & 126.47 & 366.59 \\
Bank sediment 2 & 0.436 & 3.069 & 123.26 & 154.19 \\
Average & 1.667 & 12.037 & 124.87 & 314.67 \\
Mararaban - Edege (Ref) & & & & \\
$0-15 \mathrm{~cm}$ & 5.192 & 6.628 & 43.476 & 3670.58 \\
15-30cm & 6.286 & 4.602 & 66.765 & 4408.48 \\
Average & 5.739 & 5.615 & 55.121 & 40.39 .53 \\
\hline
\end{tabular}


The enrichment factor of heavy metals understudy in the soil and sediment samples was calculated using Iron $(\mathrm{Fe})$ as a reference element and the results obtained is shown in Table 4. EF values ranging between 0.5 and 2 can be considered in the range of natural variability whereas a value greater than 2 indicates some enrichment corresponding mainly to anthropogenic inputs (Hernandez et al. 2003; Ata et al. 2009). Generally, the enrichment factors (EF) for $\mathrm{Ni}$, $\mathrm{Mn}, \mathrm{Pb}$ and $\mathrm{Cd}$ in all of the soil samples of the study area were greater than 2, highlighting the anthropogenic origin of these metals. The results of heavy metals were subjected to 1-way analysis of variance and indicated that there was no statistically significant difference $(\mathrm{P}>0.05)$ in the $\mathrm{Mn}, \mathrm{Pb}, \mathrm{Cd}, \mathrm{Ni}$, and $\mathrm{Fe}$ contents across the depth profile of soil in all the villages of the study area. There was also no significant difference $(\mathrm{P}>0.05)$ in the heavy metals content among the six sediments obtained from the mining ponds in Edege-Mbeki.

Conclusion: The concentration of heavy metals $(\mathrm{Ni}$, $\mathrm{Mn}, \mathrm{Cd}, \mathrm{Pb}$ and $\mathrm{Fe}$ ) in the soil samples analyzed were below the World Health Organization (WHO) and United States Environmental Protection Agency (USEPA) permissible limits. Hence, the soil at EdegeMbeki at the time this research was carried out does not pose a significant threat or level of contamination. Despite all of these, the geochemical parameters show that the soil/sediment samples were contaminated with $\mathrm{Pb}, \mathrm{Cd}$, and $\mathrm{Mn}$ which have their origin from anthropogenic activities.

\section{REFERENCES}

Assche, F; Clijsters, H (1990). Effects of metals on enzyme activity in plants. Plant Cell Environ. 24: 1-15.

Ata, S; Farid, M; and Soroush, M (2009). Heavy Metal Contamination and Distribution in the Shiraz Industrial Complex Zone Soil, South Shiraz, Iran. World Applied Sciences Journal, 6(3):413-425.

Bhattacharyya, P; Chakrabarti, K; Chakraborty, A; Tripathy, S; Powell, MA (2008). Fractionation and bioavailability of $\mathrm{Pb}$ in municipal solid waste compost and $\mathrm{Pb}$ uptake by rice straw and grain under submerged condition in amended soil. Geosciences Journal, 12 (1), $41-45$.

Bhupander, K; Sanjay, K, Meenu, M; Prakash, D; Singh, SK; Sharma, CS; Mukherjee, DP (2011). An assessment of heavy metals in sediments from two tributaries of lower stretch of Hugli estuary in West Bengal. Archives of Applied Science Research, 3 (4): 139-146

Dai, J; Becquer, T; Rouiller, J; Reversat, G; BernhardReversat, F; Lavelle, P (2004). Influence of heavy metals on $\mathrm{C}$ and $\mathrm{N}$ mineralisation and microbial biomass in $\mathrm{Zn}-, \mathrm{Pb}-, \mathrm{Cu}-$, and Cd-contaminated soils. Applied Soil Ecology, 25(2), 99-109. doi: 10.1016/j.apsoil.2003.09.003

Dembitsky, V (2003). Natural occurrence of arseno compounds in plants, lichens, fungi, algal species, and microorganisms. Plant Sci. 165: 1177-1192

Garrido, S; Campo, GMD; Esteller, MV; Vaca, R; Lugo, J (2002). Heavy metals in soil treated with sewage sludge composting, their effect on yield and uptake of broad bean seeds (Vicia faba L.). Water, Air, and Soil Pollution, 166, 303-319. 12/05/2014.

Hernadez, L; Probst, JL; Ulrich, E (2003). Heavy Metal Distribution in Some Frech Forest Soil, Evidence for Atmospheric Contamination. The Science of the Total Environment, 312: 195-219.

Ingram, J; Anderson, J (1993). Tropical soil biology and fertility (2nd ed.). Wallingford, UK: CABI.

Majiya, MH; Nuhu. AA; Sallau, MS; Hussaini, MM; Mohammed, AK (2015). Zamfara lead poisoning saga: Comparison of lead contamination level of water samples and lead poisoning in Bagega Artisanal gold mining district, Nigeria. Journal of Chemical and Pharmaceutical Research, 7(3):7-12

Manohar, S; Jadia, CD; Fulekar, MH (2006). Impact of ganesh idol immersion on water quality. Indian $J$. Environ. Prot. 27(3): 216-220

Nriagu, JO (1989). A global Assessment of Natural sources of Atmospheric Trace Metals. Nature, 338: 47-49

Ologundudu, F; Abiya, S; Akinnifesi, O; Akadiri, S (2019). Assessment of Heavy Metal Pollution in a Gold Mining Site in Southwestern Nigeria. Biomedical Journal of Scientific \& Technical Research, 12(4). doi: 10.26717/bjstr.2019.12.002276

Ong, MC; Menier, DZ; Shazili, NAM; Kamaruzzaman, BY (2012). Geochemical Characteristics of Heavy Metals Concentration in Sediments of Quiberon Bay Waters, South Brittany, France. Oriental Journal of Chemistry, 29(1):39-45.

Radojevic, M; and Bashkir, VN (2006). Practical Environmental Analysis. Royal Society of Chemistry, $2^{\text {nd }}$ Edition, PP. 1-44

Schmidt, U (2003). Enhancing Phytoextraction: The effects of chemical soil manipulation on mobility, plant accumulation, and leaching of heavy metals. $J$. Environ. Qual. 32: 1939-1954.

Taiz, L; Zeiger, E (2002). Plant Physiology. Sinauer Associates, (Eds.). Sunderland, U.S.A., pp. 690. 
Heavy Metal Pollution in a Columbite/Tantalite Mining site.....

US-EPA, (1993): Clean water act, section 503, Vol. 58, No.

323. United States Environmental Protection Agency,

Washington, D. C. Retrieved from

http://www.usepa.org 